\title{
Effects of different Fe supplies on mineral partitioning and remobilization during the reproductive development of rice (Oryza sativa L.)
}

\author{
Raul Antonio Sperotto ${ }^{1,2,3}$, Marta Wilton Vasconcelos ${ }^{4}$, Michael Andrew Grusak ${ }^{5}$ and Janette Palma Fett ${ }^{1,2^{*}}$
}

\begin{abstract}
Background: Minimal information exists on whole-plant dynamics of mineral flow through rice plants and on the source tissues responsible for mineral export to developing seeds. Understanding these phenomena in a model plant could help in the development of nutritionally enhanced crop cultivars. A whole-plant accumulation study, using harvests during reproductive development under different Fe supplies, was conducted to characterize mineral accumulation in roots, non-flag leaves, flag leaves, stems/sheaths, and panicles of Kitaake rice plants.

Results: Low Fe supply promoted higher accumulation of $\mathrm{Zn}, \mathrm{Cu}$ and $\mathrm{Ni}$ in roots, $\mathrm{Mn}, \mathrm{Ca}, \mathrm{Mg}$ and $\mathrm{K}$ in leaves and $\mathrm{Zn}$ in stems/sheaths and a smaller accumulation of Fe, $\mathrm{Mn}$ and $\mathrm{Ca}$ in roots and $\mathrm{Zn}$ and $\mathrm{Ni}$ in leaves. High Fe supply promoted higher accumulation of Fe in roots and $\mathrm{Zn}$ in leaves and a smaller accumulation of Fe in leaves and stems/sheaths and $\mathrm{Zn}, \mathrm{Cu}$ and $\mathrm{K}$ in roots. Correlation analyzes indicated that fluctuations in $\mathrm{Mn}-\mathrm{Ca}, \mathrm{Zn}-\mathrm{Cu}, \mathrm{Zn}-\mathrm{Ni}$, $\mathrm{Cu}-\mathrm{Ni}, \mathrm{Mo}-\mathrm{S}, \mathrm{Ca}-\mathrm{Mg}, \mathrm{Cu}-\mathrm{Mn}$ and $\mathrm{Cu}-\mathrm{Mg}$ concentrations in response to different Fe supplies were positively correlated in at least four of the five organs analyzed.
\end{abstract}

Conclusions: Mineral content loss analysis indicated that mineral remobilization from vegetative organs can occur in rice plants; however, for seeds to acquire minerals, vegetative remobilization is not absolutely required. Also, mineral remobilization from vegetative tissues in rice was greatly dependent of plant Fe nutrition. Remobilization was observed for several minerals from flag leaves and stems/sheaths, but the amounts were generally far below the total mineral accretion observed in panicles, suggesting that continued uptake and translocation of minerals from the roots during seed fill are probably more important than mineral remobilization.

Keywords: Biofortification, Elemental analysis, lonomics, Iron (Fe), Kitaake, Mineral partitioning, Reproductive development of rice

\section{Background}

Plants are the primary source of nutrients for human nutrition on a global basis. Staple seed crops, such as rice, supply the majority of daily dietary nutrients for billions of people. However, rice has a low density of mineral nutrients, and for those whose diets are high in staple foods, micronutrient malnutrition is widespread (Grusak and DellaPenna 1999). Biofortification, which consists of the use of plant breeding and/or transgenic approaches to

\footnotetext{
* Correspondence: jpfett@cbiot.ufrgs.br

'Centro de Biotecnologia, Universidade Federal do Rio Grande do Sul, 91501-970, Porto Alegre, RS, Brazil

2Departamento de Botânica, Universidade Federal do Rio Grande do Sul, 91501-970, Porto Alegre, RS, Brazil

Full list of author information is available at the end of the article
}

develop new cultivars with the potential to increase the nutrient concentration of edible portions of crop plants (White and Broadley 2005), has emerged as one possible solution to alleviate malnutrition. Despite the increasing number of studies about the physiology and regulation of uptake of several minerals from the rhizosphere, the lack of knowledge about how minerals are moved into or out of vascular tissues, translocated to vegetative tissues and loaded into seeds is one of the barriers to seed biofortification (Colangelo and Guerinot 2006).

Initial seed biofortification efforts for $\mathrm{Fe}$ and $\mathrm{Zn}$ in rice have focused on increasing the iron storage protein ferritin (Goto et al. 1999; Vasconcelos et al. 2003) or root ferric reductase activity (Vasconcelos et al. 2004). The transgenic plants showed overaccumulation of minerals 
in leaves, but only a small increase in seeds. Grain $\mathrm{Zn}$ and $\mathrm{Fe}$ concentrations were increased in barley (Hordeum vulgare) expressing the $\mathrm{Zn}$ transporter ZIP1 from Arabidopsis thaliana (Ramesh et al. 2004), and were decreased in wheat (Triticum aestivum) expressing RNAi constructs that lowered NAM family gene expression (Uauy et al. 2006). Vasconcelos et al. (2006) constitutively expressed the root ferric reductase FRO2 from A. thaliana in soybean and observed that, in certain hydroponic growth conditions, the transgenic plants showed a threefold increase in leaf Fe concentration, but only a $10 \%$ increase in seed Fe. Similar results were found with the brz mutant of Pisum sativum, which overaccumulates $\mathrm{Fe}$ in leaves but has normal seed Fe concentrations (Grusak 1994). Analysis of mineral overaccumulation mutants indicates that translocation of minerals to seeds is tightly regulated, and that simply increasing net mineral uptake into the plant will probably not result in seeds with higher mineral concentrations. Additional regulatory mechanisms or transport capabilities must be manipulated to improve remobilization and pass through of minerals from vegetative organs into seeds. Recently, over-expression of barley genes related to phytosiderophore synthesis resulted in enhanced Fe and $\mathrm{Zn}$ concentrations in rice unpolished and polished seeds (Masuda et al. 2008; Masuda et al. 2009). Enhanced expression of the three genes from the rice nicotianamine synthase family (OsNAS genes) also facilitated increases in $\mathrm{Fe}$ and $\mathrm{Zn}$ concentrations of rice grains (Lee et al. 2009; Zheng et al. 2010; Johnson et al. 2011; Lee et al. 2011). All of these results suggest that the most successful breeding or transgenic approaches will likely need to target multiple genes simultaneously (Waters and Grusak 2008, Sperotto et al. 2012).

It is accepted that minerals may be remobilized from vegetative sources (Hocking and Pate 1977; Himelblau and Amasino 2001), although a major portion of minerals in seeds are likely supplied through continuous uptake and translocation during reproductive growth to developing seeds. In wheat, Zn (Hocking 1994) and Fe (Garnett and Graham 2005) remobilization from leaves was observed. According to Jiang et al. (2007b), when ${ }^{65} \mathrm{Zn}$ is applied to rice leaves (either the flag leaf or the lowest senescent leaf), $45-50 \%$ is transported out of the treated leaf. From that $\mathrm{Zn}$, more than $90 \%$ is translocated to other vegetative organs; little is partitioned to the panicle parts and even less to the grains. These results suggest that, in rice plants grown under sufficient or surplus $\mathrm{Zn}$ supply, most of the $\mathrm{Zn}$ accumulated in the grain originates from uptake by roots after flowering and not from $\mathrm{Zn}$ remobilization from leaves. In another study, $\mathrm{Zn}$ was applied to rice plants in various amounts and at various stages of plant development. Analysis of the total plant $\mathrm{Zn}$ and $\mathrm{Zn}$ content in individual organs at flowering and at maturity indicated that the presence of $\mathrm{Zn}$ in grains could be fully attributed to additional $\mathrm{Zn}$ uptake after flowering, except when application rates were very low (Jiang et al. 2008). Under the latter conditions, roots, stems and sheaths contributed mostly to $\mathrm{Zn}$ allocation. None of the rice $\mathrm{Zn}$-application treatments showed that the main portion of $\mathrm{Zn}$ loaded in grain was remobilized from leaves (Jiang et al. 2008; Stomph et al. 2009). Contrastingly, Wu et al. (2010) showed that large amounts of the $\mathrm{Zn}$ deposited in the rice grains at maturity had been retranslocated from other plant parts and not been transported directly after uptake to the grains in the grain-filling stage. Recently, Yoneyama et al. (2010) reported that $\mathrm{Zn}$ in the rice grains and partly in the husks may be actively supplied via the phloem after mobilization from the blades of the flag and upper leaves and also by xylem-to-phloem transfer in the nodes. Fe stored in the flag and upper leaves may be transported to the grains via the phloem. Fang et al. (2008) showed that foliar application of $\mathrm{Zn}$ and Se can influence the $\mathrm{Zn}$, Se, and Fe content of rice grains; however, it was difficult to improve the Fe nutrition of rice grain by Fe spray, probably due to its limited mobility in the phloem. Waters and Grusak (2008) suggested that, in Arabidopsis, continuous uptake and translocation of minerals to source tissues during seed fill are as important, if not more important, than remobilization of previously stored minerals.

Uncovering the genetic architecture underlying mineral ion homeostasis in plants is a critical first step towards understanding the biochemical and physiological processes that regulate a plant's elemental composition. In this paper, we assess growth dynamics of the whole plant (panicles, non-flag leaves, flag leaves, stems/sheaths and roots) over the reproductive development of Oryza sativa. We also describe the concentrations and contents of ten mineral nutrients (Fe, $\mathrm{Zn}, \mathrm{Cu}, \mathrm{Mn}, \mathrm{Mo}, \mathrm{Ni}, \mathrm{Ca}, \mathrm{Mg}$, $\mathrm{K}$ and $\mathrm{S}$ ) in these organs over time. Additionally, we studied the net loss of mineral contents to investigate the potential of vegetative tissues as sources of stored minerals to be remobilized to panicles. To address the question of whether different Fe supplies could influence mineral partitioning and movement of minerals to panicles, we compared these parameters in plants treated with low, normal and high Fe concentrations.

\section{Results}

To test if different Fe supplies would influence mineral accumulation in rice organs, we cultivated Kitaake plants with 5, 20 or $200 \mu \mathrm{M}$ of Fe(III)-HEDTA from the panicle exertion (PE) until the full maturity (FM) stage. Different Fe supplies caused slight growth changes in panicles collected at the grain filling (GF) stage, while no changes were seen at the full maturity stage (Figure 1). High Fe concentration $(200 \mu \mathrm{M})$ caused a decrease of about $50 \%$ 
in panicle dry weight compared to the control concentration $(20 \mu \mathrm{M})$. However, no impact on dry weight was seen in other organs, possibly because the high Fe treatment used in this work did not lead to enough Fe accumulation to reach toxic levels (300 $\mathrm{gg} \mathrm{g}^{-1} \mathrm{DW}$ - Sahrawat 2004) in all aerial plant organs (Additional file 1). A panicle weight reduction of about $22 \%$ (not statistically significant) was seen when plants were cultivated with limited Fe supply $(5 \mu \mathrm{M})$, relative to $20 \mu \mathrm{M}$ Fe controls. Therefore, the different Fe supplies used in this work during reproductive development did not result in different dry weight in most organs. Changes in mineral contents (Additional file 2) were mainly dependent on changes in mineral concentrations.

Most of the changes in mineral concentrations resulting from different Fe supplies were found during full maturity stage. Panicle (along with flag leaf) was the organ with the least variation in mineral concentrations caused by different Fe supplies (Additional file 1, Additional file 3 and Additional file 4). At GF stage, only Fe (Additional file 1a), $\mathrm{Ni}$ (Additional file 3k) and $\mathrm{Mg}$ (Additional file 4f) concentrations showed differences due to the Fe supply. However, the decrease in panicle dry weight detected in plants cultivated with high Fe concentration during GF stage $(<50 \%$; Figure 1) resulted in decreased content in most of the minerals analyzed, except Fe, Mo and K (Additional file 2). At FM stage, none of the minerals analyzed showed difference in the content between control $(20 \mu \mathrm{M})$ and high Fe $(200 \mu \mathrm{M})$ condition (Additional file 2).

In non-flag leaves, no obvious mineral concentration dynamic could be detected. High Fe supply was responsible for higher $\mathrm{Fe}$ concentration (Additional file 1b) and for lower $\mathrm{Cu}$ (Additional file 1L), Mo (Additional file 3g), Ca (Additional file 4b) and S (Additional file 4q) concentrations. Low Fe supply was responsible for higher Mn (Additional file $3 \mathrm{~b}$ ) and $\mathrm{Ni}$ (Additional file $3 \mathrm{~L}$ ) concentrations during GF and FM; Ca (Additional file 4b) and Mg (Additional file 4g) during FM and K (Additional file 4L) during GF stage.

In flag leaves, most of the mineral concentrations (including $\mathrm{Fe}$ and $\mathrm{Zn}$ ) were not affected by different $\mathrm{Fe}$ supplies. During GF stage, only Mo (Additional file 3h), $\mathrm{Mg}$ (Additional file 4h) and S (Additional file 4r) concentrations were reduced by low and/or high Fe concentrations. During FM stage, along with $\mathrm{Mo}, \mathrm{Mg}$ and $\mathrm{S}$, the concentrations of $\mathrm{Cu}$ (Additional file $1 \mathrm{~m}$ ), Mn (Additional file 3c) and $\mathrm{Ca}$ (Additional file 4c) also presented variations according to the Fe supply.

In stems/sheaths, most of the modifications in mineral concentrations found in plants collected at the GF stage were under high Fe supply. Only Fe (Additional file 1d), $\mathrm{Cu}$ (Additional file 1n) and $\mathrm{Ni}$ (Additional file 3n) maintained similar concentrations independent of the Fe supply. During FM stage, Fe was the only mineral whose concentration increased at $200 \mu \mathrm{M}$ Fe (Additional file 1d). All the other minerals reached higher mineral concentrations at $5 \mu \mathrm{M}$ Fe.

In roots, all the minerals analyzed, except $\mathrm{K}$ (Additional file 4o) and $S$ (Additional file 4t), presented different concentrations when plants were cultivated with different Fe supplies. As expected, root Fe concentration was higher under $200 \mu \mathrm{M}$ Fe (2.2X in GF and 4.2X in FM; Additional file 1e). The opposite was found for $\mathrm{Zn}$ (Additional file $1 \mathrm{j}$ ), $\mathrm{Cu}$ (Additional file 1o), Mo (Additional file 3j) and $\mathrm{Ni}$ (Additional file 3o), with higher concentrations under lower Fe supply. K (Additional file 4o) and S (Additional file $4 \mathrm{t}$ ) concentrations were not affected by different Fe supplies.

Pearson's correlation analysis was performed in order to find relationships among the ten mineral concentrations

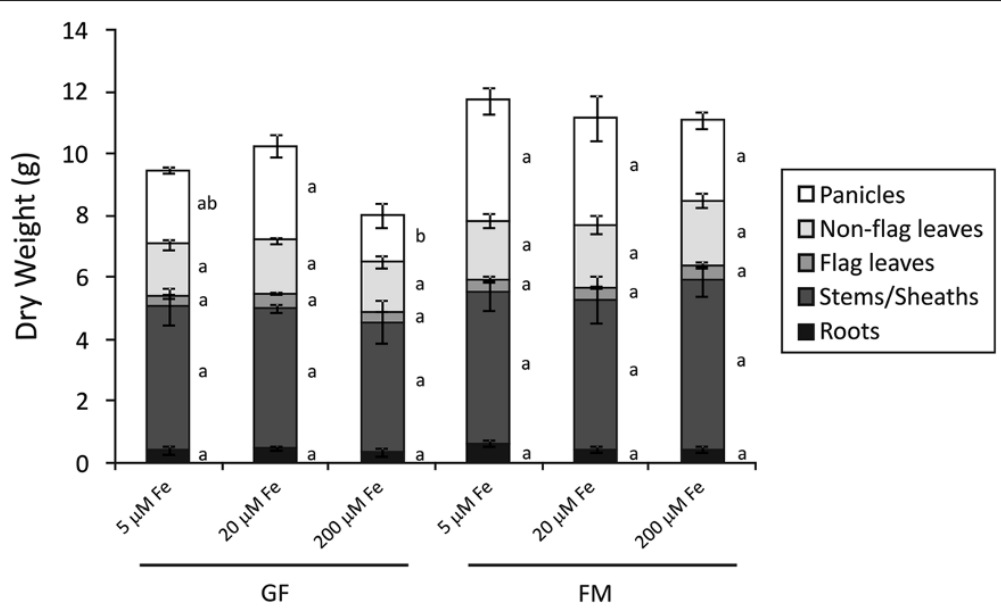

Figure 1 Dry weight of rice organs. Dry weight of panicles, non-flag leaves, flag leaves, stems/sheaths and roots collected during grain filling (GF) and full maturity (FM) stages of rice plants supplied with 5, 20 or $200 \mu \mathrm{M}$ of Fe(III)-HEDTA from panicle exertion (PE) onwards. Values are the averages of at least three samples \pm SE. Different letters indicate that the means (between different Fe supplies) are different by the Tukey HSD test $(P \leq 0.05)$. Error bars may be too small to be visible in the figure. 
in response to the different Fe supplies. As seen in Figure 2, most of the correlations were found during full maturity (FM) stage, after a longer period under different Fe supplies. Negative correlations were found mainly in roots. During grain filling (GF) stage, the only pair of minerals positively correlated in every tested organ was Mn-Ca. These were also positively correlated during FM stage in all tested organs, along with $\mathrm{Zn}-\mathrm{Cu}$. Positive correlations at FM between the pairs $\mathrm{Zn}-\mathrm{Ni}$ and $\mathrm{Cu}-\mathrm{Ni}$ were found in four of the five tested organs, except in flag leaves. Similar dynamic was found for Mo-S and $\mathrm{Ca}-\mathrm{Mg}$, which were not correlated only in panicles. $\mathrm{Cu}-\mathrm{Mn}$ and $\mathrm{Cu}-\mathrm{Mg}$ were also positively correlated in four of the five tested organs, except in roots, showing a negative correlation in this organ (Figure 2).

Differences in plant size were responsible for the high standard error in mineral contents (Additional file 2). Therefore, partition quotient (PQ) values were calculated to allow comparison of the dynamics of partitioning of minerals between the reproductive development of rice plants cultivated with different Fe supplies (Figure 3), since this approach is able to check if one mineral content is higher in one specific organ, regardless of differences in plant size. In general, non-flag leaves, flag leaves and roots were the organs which showed the higher mineral PQ variation according to Fe supply, whereas stems/sheaths was the organ with lower variation (Figure 3). For Fe, PQ values above 100 were found only in roots (Figure 3a), with higher values in plants cultivated with $200 \mu \mathrm{M}$ Fe. In all the other organs, high Fe supply was responsible for the lowest Fe PQ value, especially during FM (Additional file 5). Also, in this stage, control Fe supply $(20 \mu \mathrm{M} \mathrm{Fe})$ resulted in higher PQ values (Additional file 5). For $\mathrm{Zn}$, low Fe supply resulted in the lowest Zn PQ values in panicles, non-flag leaves and flag leaves, and high Fe supply resulted in the highest $\mathrm{Zn}$ PQ values (Figure $3 \mathrm{~b}$ ). In stems/sheaths (during FM) and roots (during both stages), the opposite was found, with higher $\mathrm{Zn}$ PQ values under low Fe supply (Figure 3b). Similar pattern was found for $\mathrm{Cu}$ (Figure 3c) and Ni (Figure 3f) PQ in roots. For Mn, no obvious pattern could be identified, except the higher PQ values in non-flag and flag leaves under Fe deprivation and in panicles and roots under Fe excess, both during FM (Figure 3d). Mo (Figure 3e) and S (Figure 3j) were the minerals with the most stable PQ values. For $\mathrm{Ca}$ (Figure $3 g$ ) and $\mathrm{Mg}$ (Figure $3 \mathrm{~h}$ ) high $\mathrm{PQ}$ values were obtained in non-flag and flag leaves during FM stage under Fe starvation. Low Fe supply also resulted in extremely reduced $\mathrm{Ca}$ PQ values in roots (Figure $3 \mathrm{~g}$ ), in relation to values seen in the other treatments.

To investigate the potential of vegetative tissues as a source of stored minerals to be remobilized to panicles, we estimated the net loss of mineral content from non-flag leaves, flag leaves and stems/sheaths, by subtracting final mineral content from the prior time point which had the highest mineral content. As seen in Figure 4, net loss of mineral content could be discerned under different Fe supplies. Under control Fe concentration $(20 \mu \mathrm{M})$, all the minerals showed content loss from GF to FM stage (Figure 4b), mostly from flag leaves but also from stems/ sheaths. However, as the flag leaves' mineral content is much lower than the stems/sheaths' content, the maximum possible contribution to panicle mineral content, assuming that the total net loss of each mineral was translocated to panicles before the final collection point, is in general higher from stems/sheaths than from flag leaves. Different

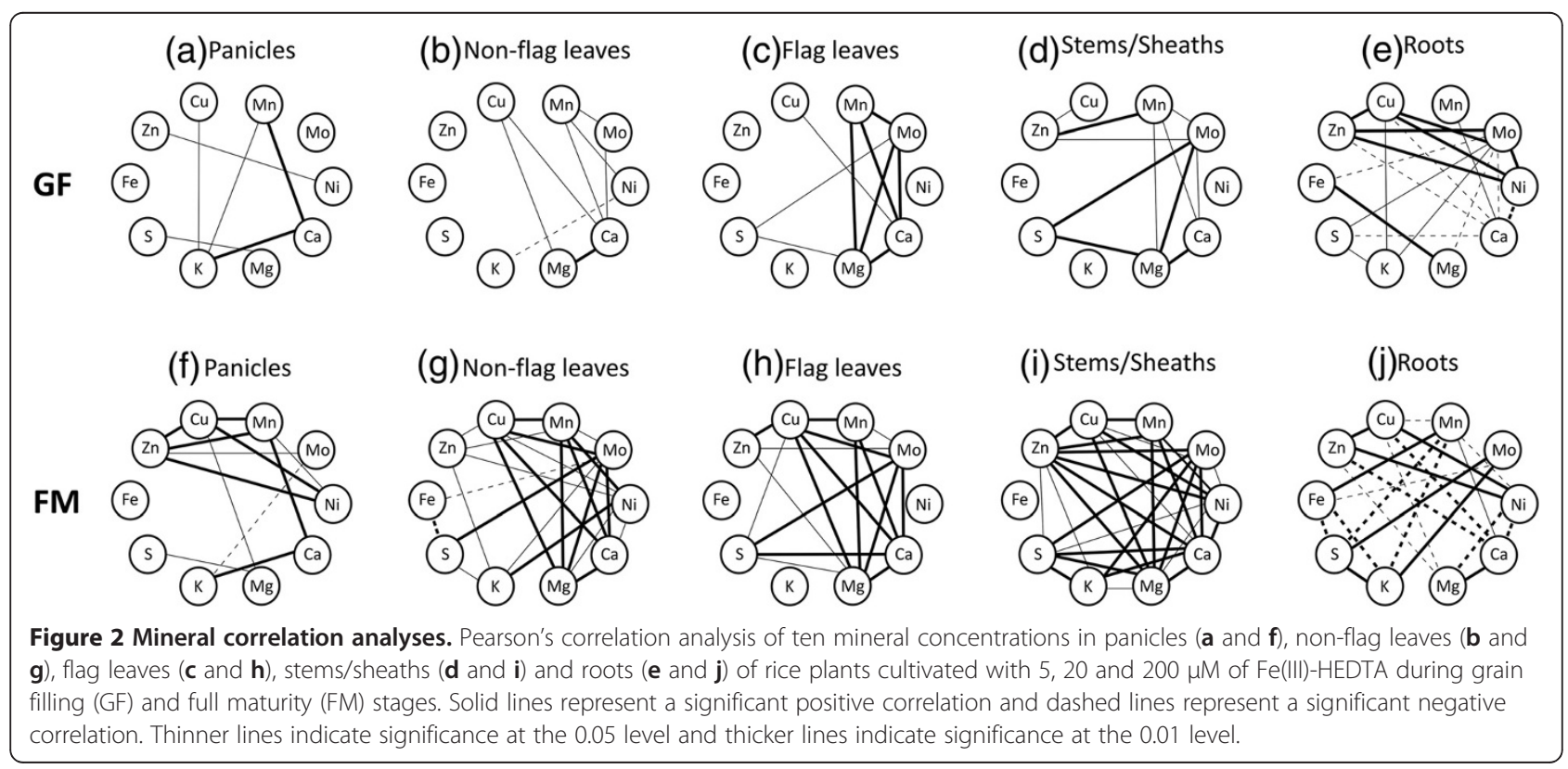




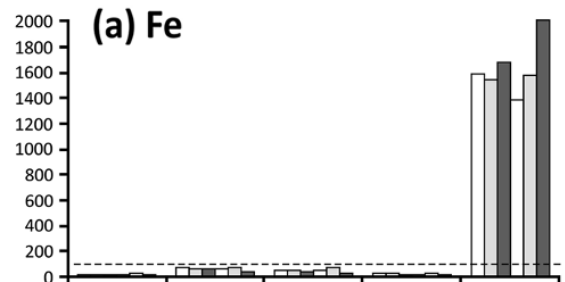

(c) $\mathrm{Cu}$
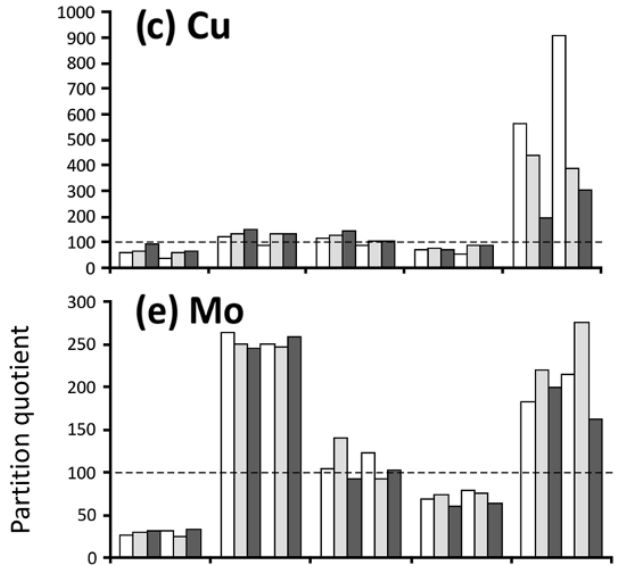

(g) $\mathrm{Ca}$
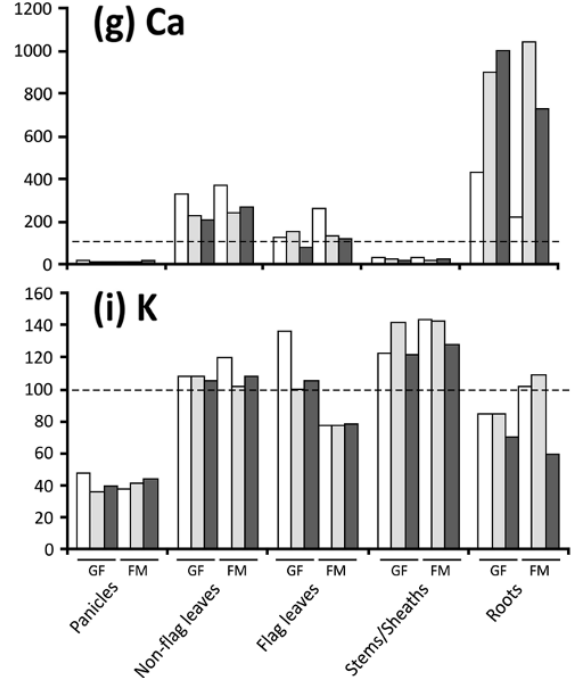
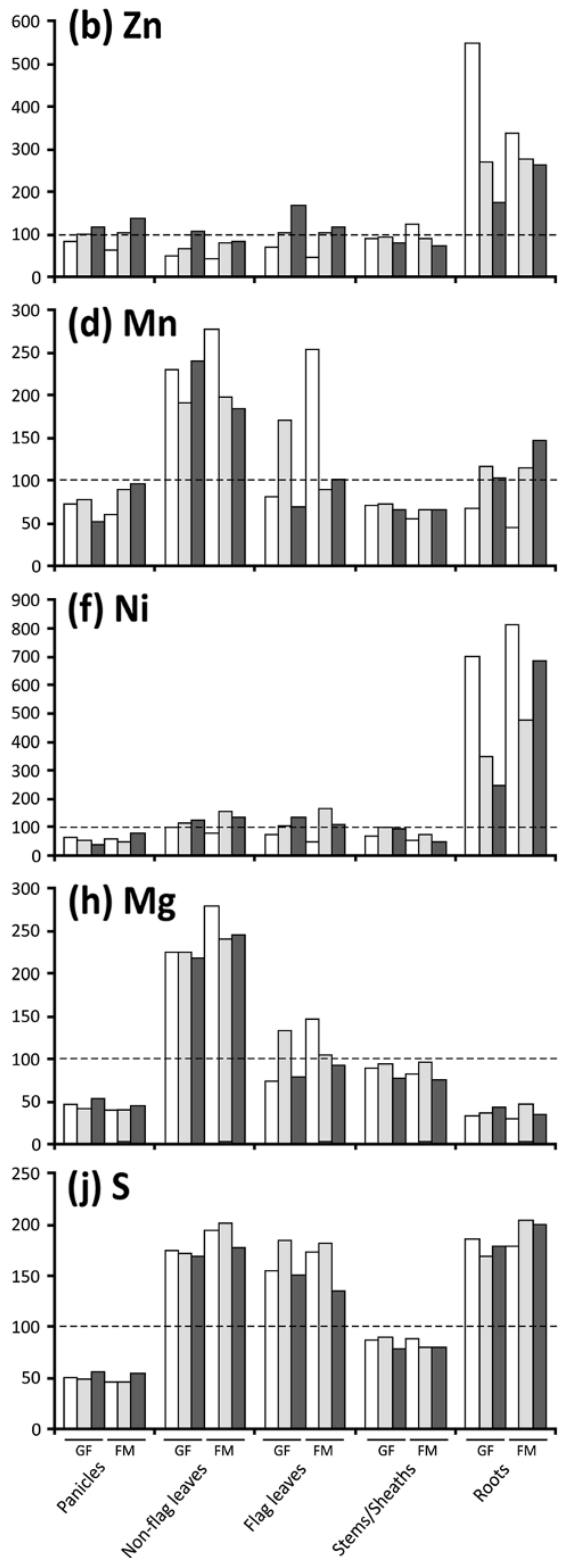

Figure 3 Partition quotients (PQ) analyses. Partition quotients of mineral elements in panicles, non-flag leaves, flag leaves, stems/sheaths and roots during grain filling (GF) and full maturity (FM) stages of rice plants supplied with 5, 20 or 200 HM of Fe(III)-HEDTA from panicle exertion onwards. Dashed horizontal line represents PQ of 100 (the percentage contribution of the organ to the plant's dry weight is the same as the percentage contribution to the plant's total content of the mineral being evaluated).

Fe supplies influenced the content loss of most of the minerals. Under limited Fe condition $(5 \mu \mathrm{M})$, only Fe, Mn and $\mathrm{Mg}$ showed a net remobilization from stems/sheaths; and $\mathrm{K}$ from flag leaves. Under high Fe condition $(200 \mu \mathrm{M})$, only $\mathrm{K}$ and $\mathrm{S}$ showed a net remobilization from flag leaves; and Ni from stems/sheaths. Surprisingly, no remobilization was found from non-flag leaves, except a minimum $\mathrm{K}$ remobilization under $20 \mu \mathrm{M}$ Fe, which could have contributed at most only with $5 \%$ of total panicle $\mathrm{K}$ content
(Figure 4e). For most of the minerals analyzed, except Ni and $\mathrm{Ca}$, the maximum possible contribution of remobilization from flag leaves and stems/sheaths to the final panicle's mineral content is less than $40 \%$, being less than $20 \%$ for $\mathrm{Fe}, \mathrm{Zn}, \mathrm{Cu}, \mathrm{Mn}$ and $\mathrm{S}$. Ni and Ca remobilization from flag leaves and mostly from stems/sheaths could be responsible for more than $100 \%$ of the final panicle content (Figure 4e), showing that remobilization does not necessarily correspond to mineral translocation to the panicles. 


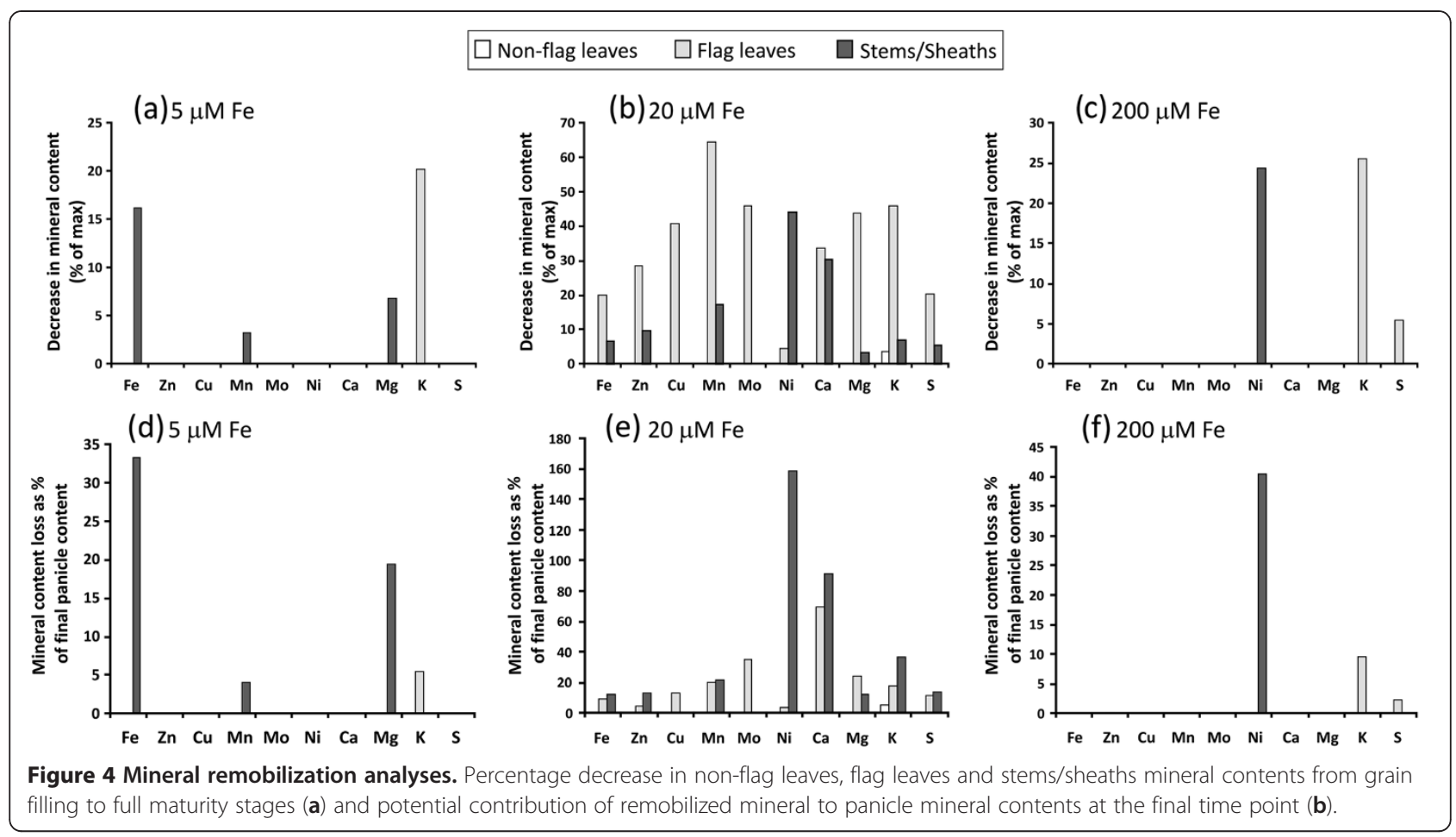

To determine whether different Fe supplies could result in different mineral export to developing seeds, we submitted rice plants to the same Fe conditions as the previous experiment (although $0 \mu \mathrm{M}$ Fe was included in this analysis). In general, the dynamics of mineral concentrations of seeds (Additional file 6) were similar to those of panicles; that is, higher $\mathrm{Fe}$ and lower $\mathrm{Zn}$ and Mo concentrations under $200 \mu \mathrm{M}$ Fe. Fe, $\mathrm{Cu}, \mathrm{Mn}, \mathrm{Mg}$ and $\mathrm{S}$ showed the lowest and $\mathrm{Zn}, \mathrm{Mo}$ and Ni showed the highest concentrations under Fe deprivation (Additional file 6).

\section{Discussion}

Plants are commonly faced with fluctuations in nutrient supply to the roots. To cope with these fluctuations, plants invoke a range of mechanisms, which include different uptake rates, changes in root morphology and physiology or storage and remobilization of mineral nutrients (Marschner 1995). In this study, we characterized organ-specific changes in dry matter and mineral (Fe, $\mathrm{Zn}, \mathrm{Cu}, \mathrm{Mn}, \mathrm{Mo}, \mathrm{Ni}, \mathrm{Ca}, \mathrm{Mg}, \mathrm{K}$ and $\mathrm{S}$ ) content to monitor the net flow of minerals into and through the rice plant over the reproductive development and under different Fe supplies. Any increase in mineral content in one organ must have resulted from uptake and translocation from the soil, or from remobilization from one organ to another. By harvesting all the organs and tracking the mineral partitioning in these organs over time, remobilization can be estimated for each mineral. In this work we used the same remobilization definition used by Waters and Grusak (2008), which is defined as the net loss of stored or recycled mineral content from one organ over time, with the mineral loss representing movement into another organ.

\section{Effects of low and high Fe supplies on mineral dynamics}

As shown in Additional file 2 and Figure 3, low Fe supply $(5 \mu \mathrm{M})$ allows higher accumulation of $\mathrm{Zn}, \mathrm{Cu}$ and $\mathrm{Ni}$ in roots; $\mathrm{Mn}, \mathrm{Ca}, \mathrm{Mg}$ and $\mathrm{K}$ in leaves and $\mathrm{Zn}$ in stems/ sheaths. On the other hand, low Fe supply allows a smaller accumulation of $\mathrm{Fe}, \mathrm{Mn}$ and $\mathrm{Ca}$ in roots and $\mathrm{Zn}$ and $\mathrm{Ni}$ in leaves. Enhancement of $\mathrm{Zn}$ uptake under low Fe supply, either as a divalent cation or complexed to phytosiderophores (Zhang et al. 1998), could explain its higher accumulation in roots. Several Fe transporters are able to transport also $\mathrm{Zn}$ and $\mathrm{Mn}$ (Korshunova et al. 1999; Eckhardt et al. 2001; Gross et al. 2003; López-Millán et al. 2004). Induction of Fe transporters under low Fe concentration could result in increased $\mathrm{Zn}$ uptake and translocation to stems/sheaths and increased $\mathrm{Mn}$ uptake and subsequent translocation to leaves, since Mn moves easily from root to shoot in the xylem-sap transpiration stream (Ramani and Kannan 1987). Possibly, uptake of Mn and $\mathrm{Cu}$ may increase in rice plants under low Fe supply, because the presence of phytosiderophores in the rhizosphere may increase the availability of these ions both in the rhizosphere itself and in the apoplast (Zhang et al. 1991). The complex $\mathrm{Cu}$-phytosiderophore can be transported into root cells by Fe-phytosiderophore transporters, although with lower affinity (Briat et al. 1995). Fertilizing a calcareous soil with an Fe-deficient solution increased $\mathrm{Cu}$ 
accumulation by roots and shoots in two wheat cultivars (Chaignon et al. 2002). It has been suggested that $\mathrm{Cu}, \mathrm{Zn}$ and Ni share a common uptake system (Kochian 1991), which could explain the higher accumulation of $\mathrm{Ni}$ in roots under low Fe supply. In fact, Eckhardt et al. (2001) proposed that the Fe transporters IRT1 and IRT2 from tomato could also transport $\mathrm{Ni}^{2+}$. Differently from our results, Silveira et al. (2007) detected increased $\mathrm{Ca}$ and K concentrations under Fe-deficiency in roots of rice, instead of in leaves. Possible explanations for such difference in $\mathrm{Ca} \mathrm{dy-}$ namic under low Fe supply are that we have used a different rice cultivar, a completely different technique for mineral detection (ICP-OES versus PIXE), different levels of Fe supply ( $5 \mu \mathrm{M}$ Fe versus Fe deprivation) and we analyzed rice organs through the course of reproductive development instead of during vegetative development.

In rice, Fe toxicity seems to occur above $500 \mu \mathrm{g} \mathrm{Fe} \mathrm{g}^{-1}$ leaf dry weight (Audebert 2006) and leads to a drastic reduction of root growth (Becker and Asch 2005). As shown in Figure 1 and Additional file 1, our plants cultivated with high Fe supply did not present reduction of root growth and did not reach toxic levels. However, the treatment resulted in decreased dry weight of panicles collected during grain filling (Figure 1). In fact, depending on the site and the cultivars used, reported critical concentrations can range from 20 to $2,500 \mu \mathrm{g} \mathrm{g}^{-1}$, indicating that factors other than Fe concentration influence the occurrence of Fe toxicity symptoms (Becker and Asch 2005). In this way, the fluctuations in mineral accumulations found in the present work do not reflect the changes promoted by Fe toxicity. High Fe supply $(200 \mu \mathrm{M})$ promoted a higher accumulation of Fe in roots and $\mathrm{Zn}$ in leaves. On the other hand, it promoted a smaller accumulation of $\mathrm{Fe}$ in leaves and stems/sheaths and $\mathrm{Zn}, \mathrm{Cu}$ and $\mathrm{K}$ in roots (Additional file 2, Figure 3 and Additional file 5). As expected, high Fe supply resulted in higher Fe accumulation in roots. However, root Fe measurements could be over-estimated. The oxidation ability of the rice root precipitates inactive Fe at the root apoplast and root-environment interface. The sampling technique used did not separate the existing oxidized $\mathrm{Fe}$ at the root surface. Thus, the root Fe content measured comprised the root $\mathrm{Fe}$ uptake and the oxidized Fe at the root surface. Most of this Fe seems to not be translocated to shoots, since smaller Fe PQ values were detected in leaves and stems/sheaths (Figure 3), even with the increased Fe content in non-flag leaves (Additional file 2). Under Fe-excess $\left(500 \mathrm{mg} \mathrm{L}^{-1}\right)$, Silveira et al. (2007) reported that rice roots and also shoots accumulate higher Fe concentration. In that work, higher concentrations of Fe were detected in I409 plants, more susceptible to Fe toxicity. Shoot concentrations detected were up to $2.5 \mathrm{X}$ higher than in E108 plants (tolerant to Fe toxicity) after 10 days of treatment. The authors suggested, therefore, that E108 plants were more resistant to excess Fe due to the possible induction of avoidance mechanisms, allowing the plant to decrease Fe translocation to shoots. This avoidance mechanism was recently reviewed by Sperotto et al. (2010). In our work, Kitaake plants seem to use the avoidance mechanism, but additional studies are needed to confirm the hypothesis that Kitaake is an Fe-excess-tolerant rice cultivar.

In accordance with our results, Silveira et al. (2007) also detected higher $\mathrm{Zn}$ concentration in shoots of plants under Fe-excess. Also in accordance to our results, smaller K (Neue et al. 1998; Ramirez et al. 2002; Mehraban et al. 2008) and $\mathrm{Cu}$ (Shao et al. 2007; Silveira et al. 2007) absorption rates under Fe-excess have already been reported in rice. It seems that, under Fe-excess, the relatively high ferrous iron concentration in the soil solution and uptake by the plant may result in K deficiency (Audebert 2006). On the other hand, it appears that proper K supply may increase Fe exclusion from roots and reduce translocation of Fe to aerial plant organs, especially to upper leaves (Sahrawat 2004).

Significant correlations were found among the ten mineral element concentrations in rice organs of plants facing different Fe supplies. In particular, $\mathrm{Mn}-\mathrm{Ca}$ and $\mathrm{Zn}-\mathrm{Cu}$ were positively correlated in all analyzed organs. $\mathrm{Zn}-\mathrm{Ni}, \mathrm{Cu}-\mathrm{Ni}$, $\mathrm{Mo}-\mathrm{S}, \mathrm{Ca}-\mathrm{Mg}$, $\mathrm{Cu}-\mathrm{Mn}$ and $\mathrm{Cu}-\mathrm{Mg}$ were positively correlated in four of the five organs (Figure 2). Most of the available data about mineral correlation in plants were obtained in grains. As far as we know, this is the first work which tries to identify similar patterns of mineral fluctuations in different plant organs due to different Fe supplies. In this way, significant positive correlations between minerals suggest that different Fe supplies promote similar changes in their concentrations. Fe concentration was positively correlated with only two minerals ( $\mathrm{Mn}$ and $\mathrm{Mg}$ ) in roots (Figure 2e and j). It is already known that Fe transporters can also transport Mn (Korshunova et al. 1999; Eckhardt et al. 2001; Gross et al. 2003; López-Millán et al. 2004) and high positive correlation between $\mathrm{Fe}$ and $\mathrm{Mn}$ was found in rice grains, along with $\mathrm{Mn}-\mathrm{Ca}, \mathrm{Zn}-\mathrm{Cu}, \mathrm{Ca}-\mathrm{Mg}$, and $\mathrm{Cu}-\mathrm{Mn}$ (Jiang et al. 2007a), in accordance with our findings. However, no Fe-Mn correlations were found in other rice organs. One possible explanation is that Mn moves easily from the root to the shoot in the xylem-sap transpirational stream (Ramani and Kannan 1987), and the mobility of Fe is more regulated (Marschner 1995). The physiological significance of the correlation between Fe-Mg is unknown, but Jiang et al. (2007a) have already detected such relation in milled rice. These authors suggest that the high number of positive correlations in rice is probably due to the interaction between ions whose chemical properties are sufficiently similar, and such similarity allows the competition for site of absorption, transport and function in plant tissues. One example was shown by Kupper and Kupper 
(1998), which reported that the heavy metals $(\mathrm{Hg}, \mathrm{Cu}, \mathrm{Cd}$, $\mathrm{Ni}$, and $\mathrm{Pb}$ ) might substitute $\mathrm{Mg}$, the central atom of chlorophyll. This could help to explain the positive correlations we found between $\mathrm{Cu}$ and $\mathrm{Mg}$ in all the organs, except in roots (Figure 2). Zeng et al. (2005) also found that $\mathrm{Mn}$ is positively associated with $\mathrm{Ca}$ in rice grains and Majumder et al. (1990) reported that uptake of $\mathrm{Mn}$ and Ca are positively correlated in rice cultivated in P-deficient soil, along with uptake of $\mathrm{Ca}$ and $\mathrm{Mg}$.

Various molecules are known to bind minerals in rice organs and could explain some of the correlations detected, such as $\mathrm{Ca}-\mathrm{K}$ in panicles, because both minerals bind to phytic acid in the aleurone layer of rice grain (Lin et al. 2005). Similarly, many of the micronutrient correlations found in various organs could be attributed to nicotianamine or deoxymugineic acid, as these are known chelators of several metal cations in plant tissues (Curie et al. 2009). However, further studies are needed to confirm the possibility of the same chelating molecules being involved in the mineral correlations detected.

\section{Mineral remobilization versus continued supply from roots}

The dynamics of mineral concentrations in seeds of plants cultivated with different Fe supplies showed that higher Fe supply results in higher Fe concentration in the seeds (Additional file 6), implying that the uptake and transport systems were operating below capacity when plants were grown with lower Fe concentrations. As previously shown by Fang et al. (2008), it is difficult to improve the Fe nutrition of rice grain, even by $\mathrm{Fe}$ spray, possibly due to its limited mobility in the phloem. Probably, enhanced root uptake combined with leaf/ stem/sheath efflux transport can be an effective way to increase the Fe concentration in rice grains.

Remobilization of reserves to supply rice seeds with minerals has been emphasized in previous studies (Jiang et al. 2007b; Fang et al. 2008; Jiang et al. 2008; Wu et al. 2010; Yoneyama et al. 2010), but the contribution of stored minerals to total seed mineral content is unclear. According to Waters and Grusak (2008), it is expected that a minimal amount of each mineral is incorporated into structural or protein molecules and thus unavailable for mobilization, and that source tissues would have to accumulate minerals in excess of this minimal amount to allow mobilization to growing tissues such as seeds. This was the case for $\mathrm{S}$ in soybean leaves (Sunarpi and Anderson 1996), where a soluble S pool was available for remobilization and an insoluble $S$ pool could not be mobilized. The size of the soluble pool was dependent on $\mathrm{S}$ nutrition. In the present study, plants fertilized with a high Fe concentration $(200 \mu \mathrm{M})$ showed only K and $\mathrm{S}$ remobilization from flag leaves and $\mathrm{Ni}$ from stems/ sheaths (Figure 4). In this case, vegetative tissues should have been able to store Fe quantities above the structural minimum, which would have provided excess Fe for remobilization. However, with the abundant Fe supply at the root level, continued uptake during seed fill may have reduced or precluded the need for remobilization to serve as a source of Fe for seeds. On the other hand, plants fertilized with low Fe concentration $(5 \mu \mathrm{M})$ showed the highest net Fe remobilization (Figure 4), probably due to reduced uptake during seed fill. Under limited Fe supply, stems/sheaths are the major Fe source for remobilization. A similar pattern was observed in other studies when $\mathrm{Zn}$ supply was very low. Under this condition, stems and sheaths contributed most to $\mathrm{Zn}$ allocation (Jiang et al. 2008). All the minerals analyzed were subject to remobilization, mostly from flag leaves, but also from stems/sheaths (Figure 4), when plants were fertilized with the control Fe concentration $(20 \mu \mathrm{M})$. These results suggest that mineral remobilization from vegetative tissues can occur in rice plants; however, for seeds to acquire minerals this remobilization is not absolutely required. Remobilization results found for Arabidopsis plants by Waters and Grusak (2008) were not exactly consistent between experiments; differences were found in the minerals that were remobilized and the amounts remobilized. CraftsBrandner (1992) also found inconsistent results in leaves of soybean, which remobilized P in one experiment, while in a second experiment no remobilization occurred, yet seeds of both experiments had comparable seed P concentrations. As shown by our results, mineral remobilization from vegetative tissues in rice is modified by plant Fe nutrition, because different Fe supplies alter the remobilization of several minerals. Also, a major proportion of mineral content in panicles probably comes from non-storage sources, that is, continued root uptake and translocation during the seed fill period. We did observe mineral remobilization mostly from flag leaves but also from stems/sheaths with $20 \mu \mathrm{M}$ Fe, and at least a portion of these minerals was likely incorporated into panicles and seeds. In the unlikely event that $100 \%$ of the content of each mineral lost from vegetative tissues went to panicles, this could account for, at most, $20 \%$ of panicle $\mathrm{Fe}, \mathrm{Zn}, \mathrm{Cu}, \mathrm{Mn}, \mathrm{Mg}$, $\mathrm{K}$ and $\mathrm{S}$. However, at least for $\mathrm{Zn}$, it is already known that most of the mineral transported out of the leaves (either the flag leaf or the lowest senescent leaf) is translocated to other vegetative organs instead of being partitioned to the panicles, and even less to the grains (Jiang et al. 2007b). We can also discard the possibility of $100 \% \mathrm{Ni}$ or Ca remobilization to panicles, since it would be responsible for more than $100 \%$ of the final panicle content (Figure 4). However, if remobilized, a significant part of this $\mathrm{Ni}$ pool would be expected to be transported to the seeds, since it is already known that Ni rapidly re-translocates from leaves to young tissues in the phloem, particularly during reproductive growth. Indeed, up to $70 \%$ of $\mathrm{Ni}$ in the shoots was transported to the seeds of soybean (Tiffin 1971). In Arabidopsis, continuous uptake and translocation of minerals to source tissues during seed fill are as important, if not 
more important, than remobilization of previously stored minerals (Waters and Grusak 2008). As shown by our results, the flag leaf is the organ with highest percentage of mineral content loss. However, considering that flag leaves have extremely low mineral content, the maximum possible contribution to panicle mineral content would be from stems/sheaths, rather than from flag leaves.

\section{Conclusion}

In summary, this study suggests that mineral accumulation throughout the reproductive development of rice organs can be affected by different Fe supplies. With respect to the translocation of minerals to panicles, remobilization from vegetative organs can occur in rice plants (and non-optimal Fe supplies can affect mineral remobilization), but apparently, for seeds to acquire minerals, vegetative remobilization is not absolutely required. In this way, continued uptake and translocation of minerals during seed fill are probably more important than remobilization of previously stored shoot minerals. Thus, in addition to targeting source tissues for increased mineral remobilization, researchers should also target root uptake and leaf/stem/sheath efflux transporters to increase mineral accumulation in the panicles and consequently in the rice seeds.

\section{Methods}

\section{Plant materials and growth conditions}

Rice (Oryza sativa L.) seeds from the fast-growing cultivar Kitaake were germinated in Petri dishes with filter paper for $8 \mathrm{~d}$ before being transferred to hydroponic solution. Plants were grown in a controlled environment chamber with $16-\mathrm{h}, 20^{\circ} \mathrm{C}$ day and $8-\mathrm{h}, 15^{\circ} \mathrm{C}$ night at the USDA-ARS Children's Nutrition Research Center, Houston, TX. Relative humidity was maintained at $50 \%$ and photon flux density during the day was $350 \mu \mathrm{mol} \mathrm{m} \mathrm{m}^{-2} \mathrm{~s}^{-1}$, supplied by a mixture of incandescent bulbs and fluorescent lamps. The standard solution for hydroponically grown plants contained $1 \mathrm{mM} \mathrm{Ca}\left(\mathrm{NO}_{3}\right)_{2}, 3 \mathrm{mM} \mathrm{KNO}, 0.5 \mathrm{mM} \mathrm{MgSO}_{4}$, $0.75 \mathrm{mM} \mathrm{K}_{2} \mathrm{SO}_{4}, 0.5 \mathrm{mM} \mathrm{KH_{2 }} \mathrm{PO}_{4}, 25 \mu \mathrm{M} \mathrm{CaCl}, 25 \mu \mathrm{M}$ $\mathrm{MnSO}_{4}, 0.5 \mu \mathrm{M} \mathrm{ZnSO}, 0.5 \mu \mathrm{M} \mathrm{CuSO}_{4}, 0.5 \mu \mathrm{M} \mathrm{H}_{2} \mathrm{MoO}_{4}$, $0.1 \mu \mathrm{M} \mathrm{NiSO}_{4}, 0.1 \mathrm{mM} \mathrm{K}_{2} \mathrm{SiO}_{3}$, and $20 \mu \mathrm{M}$ Fe(III)-HEDTA (N-hydroxyethyl-ethylenediaminetriacetic acid). All nutrients were buffered with $2 \mathrm{mM}$ MES (2,4-morpholinoethane sulfonic acid), pH 5.5 and growth solutions were replaced every 3 days. For treatments involving different Fe concentrations, Fe(III)-HEDTA concentration was adjusted to 5, 20 or $200 \mu \mathrm{M}$. Rice organs (panicles, non-flag leaves, flag leaves, stems/sheaths and roots) were collected at panicle exertion, grain filling and full maturity (R3, R5 and R9 stages, respectively, according to Counce et al. 2000). De-husked unpolished seeds were analyzed at full maturity.

\section{Elemental analysis by ICP}

All tissues were harvested and dried in a $60^{\circ} \mathrm{C}$ oven for $48 \mathrm{~h}$. Dried tissues were predigested overnight in borosilicate glass tubes with $4 \mathrm{ml}$ of redistilled $98.8 \% \mathrm{HNO}_{3}$. One milliliter of concentrated trace metal grade $\mathrm{HClO}_{4}$ was added to the predigested tissues and heated at $100^{\circ} \mathrm{C}$ for $1 \mathrm{~h}, 150^{\circ} \mathrm{C}$ for $1 \mathrm{~h}, 180^{\circ} \mathrm{C}$ for $1 \mathrm{~h}$ and then at $210^{\circ} \mathrm{C}$ to dryness (1-2 h). Digestions were performed using a heating block (Model 1016, Tecator, Hoganas, Sweden) with an exhaust-collecting manifold. Digests were resuspended in $15 \mathrm{ml}$ of redistilled $2 \% \mathrm{HNO}_{3}$. Concentrations of Fe, $\mathrm{Zn}, \mathrm{Cu}, \mathrm{Mn}, \mathrm{Mo}, \mathrm{Ni}, \mathrm{Ca}, \mathrm{Mg}, \mathrm{K}$ and $\mathrm{S}$ were determined by inductively coupled plasma-optical emission spectroscopy (CIROS ICP Model FCE12; Spectro, Kleve, Germany). Tomato leaves and rice flour standards (SRM 1573A and 1568A, respectively; National Institute of Standards and Technology, Gaithersburg, MD) were digested and analyzed along with the rice samples to ensure accuracy of the instrument calibration (Narayanan et al. 2007). Mineral content was determined by multiplying each sample's concentration by dry weight. For estimation of net mineral content loss from non-flag leaves, flag leaves and stems/sheaths, the final mineral content of each organ was subtracted from the prior time point which had the highest mineral content. For minerals that had a decrease in content, the net loss was compared with final total panicle mineral content to determine the contribution of remobilized minerals to panicle mineral content.

\section{Partition quotient calculation}

To evaluate the partitioning of minerals within a rice plant during its reproductive development and under different Fe supplies, changes in each tissue's content were normalized to changes in each tissue's weight, relative to the whole plant. The DW of each organ was calculated as a percentage of total plant weight at each time point (or at each Fe supply), and mineral content of each organ was calculated as a percentage of total plant mineral content at each time point (or at each Fe supply). Using these values, the normalized partitioning of each mineral within the plant was calculated by dividing each organ's percentage mineral content by its percentage DW, and multiplying by 100 , which we refer to as the partition quotient (PQ), as described by Waters and Grusak (2008).

\section{Statistical analyses}

When appropriate, data were subjected to analyses of variance (ANOVA) and means were compared by the Tukey HSD (Honestly Significant Differences) $(P \leq 0.05)$. The Levene's test (for homogeneity of variance) was used prior to ANOVA. Data with unequal variances were subjected to Welch analysis and means were compared 
by the Dunnett-C test. Pearson's correlation analyses were carried out using two significance levels $(P \leq 0.05$ and 0.01). All the statistical analyzes were performed using the SPSS Base 19.0 for Windows (SPSS Inc., USA).

\section{Additional files}

Additional file 1: $\mathrm{Fe}, \mathrm{Zn}$ and $\mathrm{Cu}$ concentrations. $\mathrm{Fe}, \mathrm{Zn}$ and $\mathrm{Cu}$ concentrations in panicles, non-flag leaves, flag leaves, stems/sheaths and roots collected during grain filling (GF) and full maturity (FM) stages of rice plants cultivated with 5,20 or $200 \mu \mathrm{M}$ of Fe(III)-HEDTA. Values are the averages of at least three samples \pm SE. Different letters indicate that the means (between different Fe supplies) are different by the Tukey HSD test $(P \leq 0.05)$. Error bars may be too small to be visible in the figure.

Additional file 2: Mineral contents in rice organs. Contents of $\mathrm{Fe}, \mathrm{Zn}$, $\mathrm{Cu}, \mathrm{Mn}, \mathrm{Mo}, \mathrm{Ni}, \mathrm{Ca}, \mathrm{Mg}, \mathrm{K}$ and $\mathrm{S}$ in panicles, non-flag leaves, flag leaves, stems/sheaths and roots collected from rice plants supplied with different Fe concentrations at two reproductive growth stages.

Additional file 3: $\mathrm{Mn}$, Mo and Ni concentrations. $\mathrm{Mn}, \mathrm{Mo}$ and $\mathrm{Ni}$ concentrations in panicles, non-flag leaves, flag leaves, stems/sheaths and roots collected during grain filling (GF) and full maturity (FM) stages of rice plants cultivated with 5,20 or $200 \mu \mathrm{M}$ of Fe(III)-HEDTA. Values are the averages of at least three samples \pm SE. Different letters indicate that the means (between different Fe supplies) are different by the Tukey HSD test $(P \leq 0.05)$. Error bars may be too small to be visible in the figure.

Additional file 4: $\mathrm{Ca}, \mathrm{Mg}, \mathrm{K}$ and $\mathrm{S}$ concentrations. $\mathrm{Ca}, \mathrm{Mg}, \mathrm{K}$ and $\mathrm{S}$ concentrations in panicles, non-flag leaves, flag leaves, stems/sheaths and roots collected during grain filling (GF) and full maturity (FM) stages of rice plants cultivated with 5, 20 or $200 \mu \mathrm{M}$ of Fe(III)-HEDTA. Values are the averages of at least three samples \pm SE. Different letters indicate that the means (between different Fe supplies) are different by the Tukey HSD test $(P \leq 0.05)$. Error bars may be too small to be visible in the figure.

Additional file 5: Iron partition quotient (PQ) in rice organs. Iron partition quotient in panicles, non-flag leaves, flag leaves and stems/ sheaths during grain filling (GF) and full maturity (FM) stages of rice plants cultivated with 5, 20 or $200 \mu \mathrm{M}$ of Fe(III)-HEDTA.

Additional file 6: Mineral concentrations in rice seeds. $\mathrm{Fe}, \mathrm{Zn}, \mathrm{Cu}$ $\mathrm{Mn}, \mathrm{Mo}, \mathrm{Ni}, \mathrm{Ca}, \mathrm{Mg}, \mathrm{K}$ and $\mathrm{S}$ concentrations in de-husked unpolished seeds collected during full maturity stage of rice plants cultivated with 0 , 5, 20 or $200 \mu \mathrm{M}$ of Fe(III)-HEDTA. Values are the averages of three samples \pm SE. Different letters indicate that the means (between different Fe supplies) are different by the Tukey HSD test $(P \leq 0.05)$. Error bars may be too small to be visible in the figure.

\section{Abbreviations}

FM: Full maturity; GF: Grain filling; ICP-OES: Inductively coupled plasma optical emission spectroscopy; PE: Panicle exertion; PQ: Partition quotient.

\section{Competing interests}

The authors declare that they have no competing interests.

\section{Authors' contributions}

MAG and JPF conceived and coordinated the study. RAS, MWV and MAG designed the experiments. RAS and MWV obtained the ICP data. RAS performed the statistical analyzes and drafted the manuscript. RAS, MAG and JPF prepared the final manuscript. All authors read and approved the final manuscript.

\section{Acknowledgements}

This research was supported by HarvestPlus (Agreement number 6005-05), Conselho Nacional de Desenvolvimento Científico e Tecnológico (CNPq) and Coordenação de Aperfeiçoamento de Pessoal de Nível Superior (CAPES) to JPF, and by the USDA-ARS under Agreement number 58-6250-0-008 to MAG. The contents of this publication do not necessarily reflect the views or policies of the US Department of Agriculture, nor does mention of trade names, commercial products, or organizations imply endorsement by the US Government.

\section{Author details}

'Centro de Biotecnologia, Universidade Federal do Rio Grande do Sul, 91501-970, Porto Alegre, RS, Brazil. ²Departamento de Botânica, Universidade Federal do Rio Grande do Sul, 91501-970, Porto Alegre, RS, Brazil. ${ }^{3}$ Centro de Ciências Biológicas e da Saúde, Centro Universitário UNIVATES, 95900-000, Lajeado, RS, Brazil. " CBQF/Escola Superior de Biotecnologia, Universidade Católica Portuguesa, Rua Dr. António Bernardino de Almeida, 4200-072, Porto, Portugal. ${ }^{5}$ USDA/ARS Children's Nutrition Research Center, Department of Pediatrics, Baylor College of Medicine, 1100 Bates Street, Houston, TX 77030, USA.

Received: 15 May 2012 Accepted: 14 September 2012

Published: 28 September 2012

\section{References}

Audebert A (2006) Iron partitioning as a mechanism for iron toxicity tolerance in lowland rice. In: Audebert A, Narteh LT, Kiepe P, Millar D, Beks B (eds) Iron Toxicity in Rice-based Systems in West Africa, Africa Rice Center (WARDA) Cotonou, Benin, pp 34-46

Becker M, Asch F (2005) Iron toxicity in rice-condition and management concepts. J Plant Nutr Soil Sci 168:558-573

Briat JF, Fobis-Loisy I, Grignon N, Lobréaux S, Pascal N, Savino G, Thoiron S, von Wirén N, Wuytswinkel O (1995) Cellular and molecular aspects of iron metabolism in plants. Biol Cell 84:69-81

Chaignon V, DiMalta D, Hinsinger P (2002) Fe-deficiency increases Cu acquisition by wheat cropped in a Cu-contaminated vineyard soil. New Phytol 154:121130

Colangelo EP, Guerinot ML (2006) Put the metal to the petal: metal uptake and transport throughout plants. Curr Opin Plant Biol 9:322-330

Counce PA, Keisling TC, Mitchell AJ (2000) A uniform, objective and adaptative system for expressing rice development. Crop Sci 40:436-443

Crafts-Brandner SJ (1992) Significance of leaf phosphorus remobilization in yield production in soybean. Crop Sci 32:420-424

Curie C, Cassin G, Couch D, Divol F, Higuchi K, Le Jean M, Misson J, Schikora A, Czemic P. Mari S (2009) Metal movement within the plant: contribution of nicotianamine and yellow stripe 1-like transporters. Ann Bot 103:1-11

Eckhardt U, Mas Marques A, Buckhout TJ (2001) Two iron-regulated cation transporters from tomato complement metal uptake-deficient yeast mutants. Plant Mol Biol 45:437-448

Fang Y, Wang L, Xin Z, Zhao L, An X, Hu Q (2008) Effect of foliar application of Zinc, Selenium, and Iron fertilizers on nutrients concentration and yield of rice grain in China. J Agric Food Chem 56:2079-2084

Garnett TP, Graham RD (2005) Distribution and remobilization of iron and copper in wheat. Ann Bot 95:817-826

Goto F, Yoshihara T, Shigemoto N, Toki S, Takaiwa F (1999) Iron fortification of rice seed by the soybean ferritin gene. Nat Biotechnol 17:282-286

Gross J, Stein RJ, Fett-Neto AG, Fett JP (2003) Iron homeostasis related genes in rice. Genet Mol Biol 26:477-497

Grusak MA (1994) Iron transport to developing ovules of Pisum sativum. 1. Seed import characteristics and phloem iron-loading capacity of source regions. Plant Physiol 104:649-655

Grusak MA, DellaPenna D (1999) Improving the nutrient composition of plants to enhance human nutrition and health. Annu Rev Plant Physiol Plant Mol Biol 50:133-161

Himelblau E, Amasino RM (2001) Nutrients mobilized from leaves of Arabidopsis thaliana during leaf senescence. J Plant Physiol 158:1317-1323

Hocking PJ, Pate JS (1977) Mobilization of minerals to developing seeds of legumes. Ann Bot 41:1259-1278

Hocking PJ (1994) Dry-matter production, mineral nutrient concentrations, and nutrient distribution and redistribution in irrigated spring wheat. J Plant Nutr 17:1289-1308

Jiang SL, Wu JG, Feng Y, Yang XE, Shi CH (2007a) Correlation analysis of mineral element contents and quality traits in milled rice (Oryza sativa L.). J Agric Food Chem 55:9608-9613

Jiang W. Struik PC, Lingna J, van Keulen H, Ming Z, Stomph TJ (2007b) Uptake and distribution of root-applied or foliar-applied ${ }^{65} \mathrm{Zn}$ after flowering in aerobic rice. Ann Appl Biol 150:383-391

Jiang W, Struik PC, van Keulen H, Zhao M, Jin LN, Stomph TJ (2008) Does increased Zn uptake enhance grain Zn mass concentration in rice? Ann Appl Biol 153:135-147 
Johnson AAT, Kyriacou B, Callahan DL, Carruthers L, Stangoulis J, Lombi E, Tester M (2011) Constitutive overexpression of the OsNAS gene family reveals single-gene strategies for effective Iron- and Zinc-biofortification of rice endosperm. PLoS One 6:e24476

Kochian LV (1991) Mechanisms of micronutrient uptake and translocation in plants. In: Mortvedt JJ (ed) Micronutrients in Agriculture, 2nd edn, SSSA book series \# 4. Soil Science Society of America, Madison, WI, pp 229-296

Korshunova YO, Eide D, Clark WG, Guerinot ML, Pakrasi HB (1999) The IRT1 protein from Arabidopsis thaliana is a metal transporter with a broad substrate range. Plant Mol Biol 40:37-44

Kupper H, Kupper SM (1998) In situ detection of heavy metal substituted chlorophylls in water plants. Photosynth Res 58:123-133

Lee S, Jeon US, Lee SJ, Kim YK, Persson DP, Husted S, Schjørring JK, Kakei Y, Masuda H, Nishizawa NK, An G (2009) Iron fortification of rice seeds through activation of the nicotianamine synthase gene. Proc Nat Acad Sci USA 106:22014-22019

Lee S, Persson DP, Hansen TH, Husted S, Schjoerring JK, Kim YS, Kakei Y, Masuda $H$, Nishizawa NK, An G (2011) Bio-available zinc in rice seeds is increased by activation tagging of nicotianamine synthase. Plant Biotechnol J 9:865-873

Lin L, Ockenden I, Lott JNA (2005) The concentrations and distribution of phytic acid-phosphorus and other mineral nutrients in wild-type and low phytic acid11 (Ipa 1-1) corn (Zea mays L.) grains and grain parts. Can J Bot 83:131-141

López-Millán A-F, Ellis DR, Grusak MA (2004) Identification and characterization of several new members of the ZIP family of metal transporters in Medicago truncatula. Plant Mol Biol 54:583-596

Majumder ND, Rakshit SC, Borthakur DN (1990) Genetic effect on uptake of selected nutrients in some rice ( $O$. sativa $\mathrm{L}$.) varieties in phosphorus deficient soils. Plant Soil 123:117-120

Marschner H (1995) Mineral Nutrition of Higher Plants, 2nd edn. Academic, London

Masuda H, Suzuki M, Morikawa KC, Kobayashi T, Nakanishi H, Takahashi M, Saigusa M, Mori S, Nishizawa NK (2008) Increase in iron and zinc concentrations in rice grains via the introduction of barley genes involved in phytosiderophore synthesis. Rice 1:100-108

Masuda H, Usuda K, Kobayashi T, Ishimaru Y, Kakei Y, Takahashi M, Higuchi K, Nakanishi H, Mori S, Nishizawa NK (2009) Overexpression of the barley nicotianamine synthase gene HVNAS1 increases iron and zinc concentrations in rice grains. Rice 2:155-166

Mehraban P, Zadeh AA, Sadeghipour HR (2008) Iron toxicity in rice (Oryza sativa L.) under different potassium nutrition. Asian J Plant Sci 7:251-259

Narayanan NN, Vasconcelos MW, Grusak MA (2007) Expression profiling of Oryza sativa metal homeostasis genes in different rice cultivars using a CDNA macroarray. Plant Physiol Biochem 45:277-286

Neue HU, Quijano C, Senadhira D, Setter T (1998) Strategies for dealing with micronutrient disorders and salinity in lowland rice systems. Field Crops Res 56:139-155

Ramani S, Kannan S (1987) Manganese absorption and transport in rice. Physiol Plant 33:133-137

Ramesh SA, Choimes S, Schachtman DP (2004) Over-expression of an Arabidopsis zinc transporter in Hordeum vulgare increases short-term zinc uptake after zinc deprivation and seed zinc content. Plant Mol Biol 54:373-385

Ramirez L, Classen N, Ubiera A, Werner H, Movad AM (2002) Effect of phosphorus, potassium and zinc fertilizers on iron toxicity in wetland rice (Oryza sativa L.). Plant Soil 239:197-206

Sahrawat KL (2004) Iron toxicity in wetland rice and the role of other nutrients. J Plant Nutr 27:1471-1504

Shao G, Chen M, Wang W, Mou R, Zhang G (2007) Iron nutrition affects cadmium accumulation and toxicity in rice plants. Plant Growth Regul 53:33-42

Silveira VC, Oliveira AP, Sperotto RA, Espindola LS, Amaral L, Dias JF, Cunha JB, Fett JP (2007) Influence of iron on mineral status of two rice (Oryza sativa L.) cultivars. Braz J Plant Physiol 19:127-139

Sperotto RA, Ricachenevsky FK, Stein RJ, Waldow VA, Fett JP (2010) Iron stress in plants: dealing with deprivation and overload. Plant Stress 4:57-69

Sperotto RA, Ricachenevsky FK, Waldow VA, Fett JP (2012) Iron biofortification in rice: It's a long way to the top. Plant Sci 190:24-39

Stomph TJ, Jiang W, Struik PC (2009) Zinc biofortification of cereals: rice differs from wheat and barley. Trends Plant Sci 14:123-124

Sunarpi, Anderson JW (1996) Effect of sulfur nutrition on the redistribution of sulfur in vegetative soybean plants. Plant Physiol 112:623-631

Tiffin LO (1971) Translocation of nickel in xylem exudates of plants. Plant Physiol $48: 273-277$
Uauy C, Distelfeld A, Fahima T, Blechl A, Dubcovsky J (2006) A NAC gene regulating senescence improves grain protein, zinc, and iron content in wheat. Science 314:1298-1301

Vasconcelos M, Datta K, Oliva N, Khalekuzzaman M, Torrizo L, Krishnan S, Oliveira M, Goto F, Datta SK (2003) Enhanced iron and zinc accumulation in transgenic rice with the ferritin gene. Plant Sci 164:371-378

Vasconcelos M, Musetti V, Li CM, Datta SK, Grusak MA (2004) Functional analysis of transgenic rice (Oryza sativa L.) transformed with an Arabidopsis thaliana ferric reductase (AtFRO2). Soil Sci Plant Nutr 50:1151-1157

Vasconcelos M, Eckert H, Arahana V, Graef G, Grusak MA, Clemente T (2006) Molecular and phenotypic characterization of transgenic soybean expressing the Arabidopsis ferric chelate reductase gene FRO2. Planta 224:1116-1128

Waters BM, Grusak MA (2008) Whole-plant mineral partitioning throughout the life cycle in Arabidopsis thaliana ecotypes Columbia, Landsberg erecta, Cape Verde Islands, and the mutant line ys/7ys/3. New Phytol 177:389-405

White PJ, Broadley MR (2005) Biofortifying crops with essential mineral elements Trends Plant Sci 10:586-593

Wu CY, Lu LL, Yang XE, Feng Y, Wei YY, Hao HL, Stoffella PJ, He ZL (2010) Uptake, translocation, and remobilization of Zinc absorbed at different growth stages by rice genotypes of different Zn densities. J Agric Food Chem 58:6767-6773

Yoneyama T, Gosho T, Kato M, Goto S, Hayashi H (2010) Xylem and phloem transport of $\mathrm{Cd}, \mathrm{Zn}$ and Fe into the grains of rice plants (Oryza sativa L.) grown in continuously flooded Cd-contaminated soil. Soil Sci Plant Nutr 56:445-453

Zeng YW, Shen SQ, Wang LX, Liu JF, Pu XY, Du J, Qiu M (2005) Correlation of plant morphological and grain quality traits with mineral element contents in Yunnan rice. Rice Sci 12:101-106

Zhang FS, Römheld V, Marschner H (1991) Diurnal rhythm of release of phytosiderophores and uptake rate of zinc in iron-deficient wheat. Soil Sci Plant Nutr 37:671-678

Zhang X, Zhang F, Mao D (1998) Effect of iron plaque outside roots on nutrient uptake by rice (Oryza sativa L.): Zinc uptake by Fe-deficient rice. Plant Soil 202:33-39

Zheng L, Cheng Z, Ai C, Jiang X, Bei X, Zheng Y, Glahn RP, Welch RM, Miller DD, Lei $X G$, Shou H (2010) Nicotianamine, a novel enhancer of rice iron bioavailability to humans. PLoS One 5:e10190

doi:10.1186/1939-8433-5-27

Cite this article as: Sperotto et al:: Effects of different Fe supplies on mineral partitioning and remobilization during the reproductive development of rice (Oryza sativa L.). Rice 2012 5:27.

\section{Submit your manuscript to a SpringerOpen ${ }^{\circ}$ journal and benefit from:}

- Convenient online submission

$\checkmark$ Rigorous peer review

- Immediate publication on acceptance

- Open access: articles freely available online

- High visibility within the field

- Retaining the copyright to your article

Submit your next manuscript at $>$ springeropen.com 